\title{
Patient empowerment within a coronary care unit: Insights for health professionals drawn from a patient satisfaction survey
}

\author{
David Lewin, Stewart Piper \\ Homerton School of Health Studies, Education Centre, Peterborough District Hospital, Thorpe \\ Road, Peterborough, Cambridgeshire PE3 6DA, UK
}

\section{Keywords}

Patient empowerment

Coronary care

Survey research

\section{Summary}

The aim of this exploratory study was to investigate coronary care patients' perceptions of their care and interventions related to empowerment and strengthening patient choice. The study, conducted in one acute National Health Service (NHS) Trust in Cambridgeshire, England, and completed in 2002, employed a prospective survey design. The research used a self-completion, pilot, postal questionnaire, including closed, open and scaled questions as the main method of data collection. From a total of 200 eligible patients, an unselected, consecutive sample of 142 in-patients consented to participate, of whom 103 returned the questionnaire - a response rate of $73 \%$. In contrast to much published literature, this study demonstrated that empowerment issues involving the rights of coronary care patients to be primary decision makers, managers of their illnesses and ultimate arbiters of their treatment and care were of minimal concern to all but a few. Almost $90 \%$ of patients were content to entrust their care exclusively to health professionals based on their confidence in the clinical expertise of the medical and nursing staff. Findings suggested that, while respondents were well-satisfied with their care, the ethos of patient empowerment was of peripheral concern and readily abdicated in the face of acute illness.

\section{Introduction}

The concept of empowerment first assumed prominence in the 1970s as a feature of health improvement (WHO, 1978) and by the 1990s had pervaded the health and social care discourse (Skelton, 1994;Gilbert, 1995; Humphries, 1996; Rodwell, 1996). Recent Department of Health (DoH) policy (DoH, 1998, 2000), the RCN (2003) and the NMC (2004) have continued to emphasise the primacy of patient empowerment and the related themes of informed choice (DoH, 2004) and partnership working with patients (NMC, 2005). However, despite several authors attempting a concept analysis, (Skelton,1994; Gilbert, 1995; Jacob, 1996; Rodwell, 1996; Kuokkanen and LeinoKilpi, 2000; Byrt and Dooher, 2002), empowerment has been difficult to implement and measure in practice (Gibson, 1995; Laverack and Wallerstein, 2001). It remains an elusive, complex and contested multidimensional concept (Tones, 1998) with meagre empirical evidence to show that it can effect clinically meaningful outcomes such as how patients feel or function. Moreover, Henwood et al. (2003) contend that some patients wish to adopt a passive role in relationships with their general practitioners and opt to devolve responsibility for decision making to their medical practitioners. Compatible with Henwood et al. (2003), this article reports on patients' perceptions of empowerment in a coronary care setting which also contradict the received wisdom that patients necessarily wish to be empowered.

\section{Literature review}

Four dimensions of empowerment frequently identified in the literature (Hogg, 1999; Wilkinson and Miers, 1999; Kemshall and Littlechild, 2000) include firstly individual patients' beliefs and abilities to have power, influence and control. Second is the willingness and commitment of health professionals to empower patients and thirdly, a perceived change in 
the power or control over their care by the latter. The fourth dimension emphasises particularly equality of opportunity and freedom from discrimination. Byrt and Dooher (2002) suggest that empowerment is incomplete unless all four dimensions are addressed.

Empowerment is thus about shifting practice away from 'top-down' expert directed health care, based on assessment of need from a professional perspective, to promoting patient led, more 'bottom-up' decision making. It is concerned to foster a more collaborative, less hierarchical, non-coercive and power-sharing partnership based on mutual trust and respect (Gibson, 1991; Malin and Teasdale, 1991; Piper and Brown, 1998). This accords with the developing consumer and advocacy culture in the NHS exemplified by Patient Advice and Liaison Services (DoH, 2002), the Expert Patient (DoH, 2001) and a belief that consumers often knew best about their individual health, had a right to be involved in all related decisions and that there should be mutual respect between consumers and professionals (NHSE, 1997). However, for Hewitt-Taylor (2004), it is too simplistic to assume that the imbalance of power can be resolved by one party handing over their surplus to the other, and that this ignores the complexity of power related issues and the context of the relationship. McQueen et al. (2002) go further in contending that empowerment is creating a 'false democracy' because of the imbalance in expertise, that the process may undermine 'clinical effectiveness' and thus contradict evidence based practice.

In an effort to measure indicators of empowerment in a complex, clinical milieu, empowerment was defined in this study as a technology used for practical, day-to-day and face-to-face encounters with patients (Tones, 2001). The research instrument focused on interventions which employed simple, pragmatic, enabling strategies to enhance patients' control over their health (Tones, 1991). These included the giving and receiving of information about treatment and care, having a voice in the choice and direction of clinical management, providing consent prior to clinical procedures, being respected as an individual, choosing where to be nursed as an inpatient and having the knowledge and confidence to manage at home following discharge from hospital. It was linked to ideas of self-care, selfresponsibility and personal control (Kendall, 1998) and patients demonstrating the ability, confidence vision and insight to enhance their personal and clinical well-being.

\section{Aim and objectives of the survey}

The research was directed by a multi-disciplinary steering group, closely associated with the coronary care unit, including doctors, nurses, pharmacists, educationalists, clinical psychologists, dietitians and a patient representative. The aim of the study was to investigate coronary care patients' perceptions of their degree of empowerment. Key objectives were to explore patients' perceptions, views and recollections about their experiences on a coronary care unit and identify a notional patient empowerment index or benchmark based on specific local evidence within a clinical discipline.

\section{Methods}

Prior to commencing the study, the research team gained approval from the Local Research Ethics Committee, the School Research Sub-committee and obtained clearance from the local data protection officer.

An unselected, consecutive sample of 142 patients admitted to coronary care in an NHS Trust in Cambridgeshire formally consented to participate in the study. A total of 103 returned questionnaires giving a response rate of $73 \%$. Of these 103,11 respondents failed to complete the occasional question, notably items in a Likert-type scale. All eligible patients were approached towards the end of their stay in hospital by a cardiac liaison nurse (a member of the research team) who discussed with them the context and background to the study. Patients were invited to take part, but allowed time to think about it and confer with relatives if they wished. Those agreeing to take part signed the consent form and confirmed their discharge addresses. There was some evidence, from previous satisfaction studies conducted by the research department, that patients tended to make more reflective, considered judgements about their hospital stay during the period following their discharge, and the researchers wished to ensure that patients did not feel obliged to consent to a 
research study which might be misconstrued as an integral component of their in-patient care. Postal questionnaires were sent to patients a month following their discharge, and they were asked to return them in a stamped, addressed envelope provided.

\section{Inclusion criteria and exclusion criteria}

Patients were recruited who, in the opinion of the medical and nursing staff, were deemed fit for discharge. They included adult men and women between the ages of 30 and 90 years with confirmed myocardial infarctions, angina and arrythmias. Exclusion criteria included all patients:

- With limited understanding of the English language for whom translation arrangements would be necessary to meet the criterion of informed consent.

- With learning and comprehension difficulties.

- Admitted for very short procedures such as elective cardioversion.

- Who were children less than 16 years of age.

- Who were regarded by the medical and nursing staff as being in a vulnerable group, for example, the mentally ill.

The study employed a postal survey design, and drew on well-established theoretical and conceptual principles for exploring patient perceptions (Hopkins, 1992; Robson, 1993). A pilot, self-completion questionnaire was developed as the main method of data collection for the reasons most commonly cited: relatively low costs of data collection and processing, avoidance of interviewer bias, and the ability to reach widely dispersed respondents (Oppenheim, 1992). The published literature was considered in detail and the balance and relevance of topics were informed by the Clinical Accountability, Service Planning and Evaluation (CASPE) research team's work on patient perception surveys (Smith, 1992), Streiner's and Norman's (1989) work on the development of health measurement scales and material was reviewed by all members of the project steering group. In summary, the published literature was used to inform an appropriate analytic survey design and refine the content, form, order, analysis and interpretation of questions about topics identified by patients as important to their care. The tool was pre-piloted on five patients, who all managed to complete it easily within 10 min. A Flesh-Kincaid Reading Ease test (Wikipedia, 2005) was performed on the pilot questionnaire and a score of 68 obtained which equates with the readability index of the Reader's Digest magazine.

The final questionnaire, contained a range of modules with closed (pre-coded) and open (free-response) questions, reflecting principles of survey research outlined by Moser and Kalton (1977) and Munn and Drever (1995). It was therefore possible to claim for this research instrument at least some measure of face and content validity since it incorporated key elements of the patient empowerment and satisfaction literature. The questionnaire, obtainable from the authors, invited respondents to comment on their perceptions of the service received as patients during their stay in the coronary care unit. Some items, in the form of a Likert-scale, asked them to reflect on some general questions about their stay in hospital and the questionnaire concluded with some demographic information. 


\begin{tabular}{|c|c|c|}
\hline & No. of responses & $\%$ \\
\hline \multicolumn{3}{|l|}{ Gender } \\
\hline Male & 75 & 72.8 \\
\hline Female & 28 & 27.2 \\
\hline Total & 103 & 100.0 \\
\hline \multicolumn{3}{|l|}{ Age group in years } \\
\hline $36-40$ & 3 & 2.9 \\
\hline $41-50$ & 11 & 10.7 \\
\hline $51-60$ & 21 & 20.4 \\
\hline $61-70$ & 33 & 32.0 \\
\hline $71-80$ & 29 & 28.2 \\
\hline $81-90$ & 6 & 5.8 \\
\hline Total & 103 & 100.0 \\
\hline \multicolumn{3}{|l|}{ Marital status } \\
\hline Married & 55 & 53.4 \\
\hline Remarried & 23 & 22.3 \\
\hline Widowed & 13 & 12.6 \\
\hline Divorced & 5 & 4.9 \\
\hline Single (never married) & 2 & 1.9 \\
\hline $\begin{array}{l}\text { Unmarried but living as } \\
\text { partners }\end{array}$ & 2 & 1.9 \\
\hline Non response & 2 & 1.9 \\
\hline Separated & 1 & 1.0 \\
\hline Total & 103 & $99.9^{\mathrm{a}}$ \\
\hline \multicolumn{3}{|l|}{ Country of birth } \\
\hline England & 93 & 90.3 \\
\hline Elsewhere in Europe & 3 & 2.9 \\
\hline Outside Europe & 3 & 2.9 \\
\hline Scotland & 2 & 1.9 \\
\hline Northern Ireland & 1 & 1.0 \\
\hline Wales & 1 & 1.0 \\
\hline Total & 103 & 100.0 \\
\hline
\end{tabular}




\begin{tabular}{|c|c|c|}
\hline Statement & Responses & $\%$ \\
\hline $\begin{array}{l}\text { When it comes to coronary care, the doctors and nurses are the real experts and I really did not mind being told by } \\
\text { them what to do for the best especially since they made it nice and clear }\end{array}$ & 44 & 47.8 \\
\hline $\begin{array}{l}\text { When it comes to coronary care, decisions about treatment and care are really quite complex and in reality I was } \\
\text { more than happy to leave it all to the doctors and nurses }\end{array}$ & 23 & 25.0 \\
\hline $\begin{array}{l}\text { When it comes to coronary care, I felt very much out of my depth and was happy for the doctors and nurses to } \\
\text { take charge whereas usually I have the knowledge, skills and confidence to organise my own life very well }\end{array}$ & 10 & 10.9 \\
\hline $\begin{array}{l}\text { When it comes to coronary care, I think the best approach is a partnership between health care professionals and } \\
\text { patients in which both contribute more or less equally to decisions about treatment and care }\end{array}$ & 5 & 5.4 \\
\hline When it comes to coronary care, I felt it was mainly up to me to get well again for the sake of my family and myself & 3 & 3.3 \\
\hline $\begin{array}{l}\text { When it comes to coronary care, I feel doctors and nurse are the experts and the patients should be informed at all } \\
\text { times as to what is happening to them }\end{array}$ & 1 & 1.1 \\
\hline $\begin{array}{l}\text { This depends on the patients and how much they understand and should be tailored to suit the patient's level of } \\
\text { know of knowledge and interest }\end{array}$ & 1 & 1.1 \\
\hline $\begin{array}{l}\text { I was more than happy to leave it all to doctors and nurses, and felt fully confident with all my treatment at the } \\
\text { hospitals }\end{array}$ & 1 & 1.1 \\
\hline I had all the care from all the staff and my feeling better was through them & 1 & 1.1 \\
\hline I believe all statements apply & 1 & 1.1 \\
\hline I received first class treatment from all the staff involved & 1 & 1.1 \\
\hline I have a responsibility to get well again guided by the medical teams but they are the experts & 1 & 1.1 \\
\hline Total & $92^{\mathrm{a}}$ & $100.1^{b}$ \\
\hline $\begin{array}{l}{ }^{a} \text { Responses calculated on } 92 \text { patients who completed this question. } \\
\text { b Percentages rounded to one decimal place. }\end{array}$ & & \\
\hline
\end{tabular}


The survey generated largely categorical and ordinal data (illustrated in Tables 1-6) from which numerical values were computed. Internal consistency analysis was calculated for the Likert-scale using Cronbach's alpha coefficients. This has an important use as a measure of instrument reliability since, by using a technique of mean inter-correlation, it assesses the extent to which a set of test items can be treated as measuring a multidimensional variable such as patient empowerment. Data were analysed using SPSS statistics and data presentation software (SPSS, 1999, Version 10). A formal power calculation to determine sample size was not undertaken for three reasons since the research team had no reliable, previous empowerment data relating to coronary care patients, minimal understanding of the variability of key empowerment variables and were not testing a hypothesis.

\begin{tabular}{|c|c|c|}
\hline & Responses & $\%$ \\
\hline \multicolumn{3}{|l|}{ Doctors } \\
\hline Very well-informed & 49 & 49.0 \\
\hline Well-informed & 44 & 44.0 \\
\hline Neither well nor poorly informed & 7 & 7.0 \\
\hline Total & $100^{\mathrm{a}}$ & 100.0 \\
\hline \multicolumn{3}{|l|}{ Nurses } \\
\hline Very well-informed & 56 & 56.6 \\
\hline Well-informed & 38 & 38.4 \\
\hline Neither well nor poorly informed & 5 & 5.1 \\
\hline Total & $99^{a}$ & 100.0 \\
\hline
\end{tabular}

\section{Findings}

Seventy five patients (73\%) in the sample were male (mean age 63 years) and $28(27 \%)$ were female (mean age 68 years). Nearly all (95\%) described themselves of white origin and born in the United Kingdom (94\%). About four-fifths of the sample (78\%) were either married or living with their partners.

Patients were invited either to express their points of view with respect to a series of statements or to formulate their own personal statements if they wished. Table 2 suggests that $80 / 92(87 \%)$ of respondents who answered this question appeared content to entrust their care to the health professionals as experts. Only five research subjects, of whom four were women, subscribed to the idea of a partnership approach between patients and health care professionals.

Patients were asked about how well-informed about their cardiac condition they were by doctors and nurses. Table 3 summarises results regarding the 100 patients who replied in respect of doctors and 99 regarding nurses. Patterns are similar for both groups with about $94 \%$ of patients reporting that they were well-informed. However, for about $6 \%$ of research subjects overall, information giving appears to be no better than average. 


\begin{tabular}{|c|c|c|c|c|c|c|}
\hline Statement & $\begin{array}{l}\text { No. of } \\
\text { responses }\end{array}$ & $\begin{array}{l}\text { Strongly } \\
\text { agree (\%) }\end{array}$ & $\begin{array}{l}\text { Agree } \\
(\%)\end{array}$ & $\begin{array}{l}\text { No strong } \\
\text { view (\%) }\end{array}$ & $\begin{array}{l}\text { Disagree } \\
(\%)\end{array}$ & $\begin{array}{c}\text { Strongly } \\
\text { disagree (\%) }\end{array}$ \\
\hline $\begin{array}{l}\text { (a) The staff gave me clear } \\
\text { information on how best to } \\
\text { manage my illness }\end{array}$ & 96 & $25(26.0)$ & 57 (59.4) & $9(9.4)$ & $5(5.2)$ & $0(0.0)$ \\
\hline $\begin{array}{l}\text { (b) Overall, I felt that I was talked } \\
\text { at by the staff rather than listened } \\
\text { to }\end{array}$ & 96 & $1(1.0)$ & $7(7.3)$ & $12(12.5)$ & 45 (46.9) & 31 (32.3) \\
\hline $\begin{array}{l}\text { (c) I wish I could have had more } \\
\text { say in my treatment and care }\end{array}$ & 94 & $1(1.1)$ & $7(7.3)$ & $23(24.5)$ & $45(46.9)$ & $18(19.1)$ \\
\hline $\begin{array}{l}\text { (d) The subject of my treatment } \\
\text { was never properly discussed in } \\
\text { any real detail }\end{array}$ & 97 & $5(5.2)$ & $8(8.2)$ & $12(12.4)$ & $47(48.5)$ & $25(25.8)$ \\
\hline $\begin{array}{l}\text { (e) I never really knew what was } \\
\text { happening from } 1 \text { day to the next }\end{array}$ & 96 & $2(2.1)$ & $7(7.3)$ & $9(9.4)$ & $40(41.7)$ & $38(39.6)$ \\
\hline $\begin{array}{l}\text { (f) I felt that I always gave my } \\
\text { consent before a clinical } \\
\text { procedure was carried out }\end{array}$ & 95 & $25(26.3)$ & $45(47.4)$ & $14(14.7)$ & $9(9.5)$ & $2(2.1)$ \\
\hline $\begin{array}{l}\text { (g) I always felt that the purpose } \\
\text { of my prescribed medication was } \\
\text { fully explained }\end{array}$ & 96 & $26(27.1)$ & $49(51.0)$ & $10(10.4)$ & $11(11.5)$ & $0(0.0)$ \\
\hline $\begin{array}{l}\text { (h) Overall, the staff could have } \\
\text { been more friendly and } \\
\text { approachable }\end{array}$ & 97 & $6(6.2)$ & $4(4.1)$ & $5(5.2)$ & 25 (25.8) & $57(58.8)$ \\
\hline $\begin{array}{l}\text { (i) Personally, I would have liked } \\
\text { the opportunity to read my } \\
\text { medical notes }\end{array}$ & 97 & $9(9.3)$ & $19(19.6)$ & $34(35.1)$ & 29 (29.9) & $6(6.2)$ \\
\hline $\begin{array}{l}\text { (j) The staff did everything } \\
\text { possible to help me with anxieties } \\
\text { over my illness }\end{array}$ & 96 & $42(43.8)$ & $43(44.8)$ & $8(8.3)$ & $3(3.1)$ & $0(0.0)$ \\
\hline $\begin{array}{l}\text { (k) The staff were always so } \\
\text { helpful and understanding over } \\
\text { visiting times }\end{array}$ & 97 & $42(43.3)$ & $52(53.6)$ & $3(3.1)$ & $0(0.0)$ & $0(0.0)$ \\
\hline $\begin{array}{l}\text { (I) I felt that I was being treated as } \\
\text { an individual by all members of } \\
\text { staff }\end{array}$ & 98 & $50(51.0)$ & $40(40.8)$ & $7(7.1)$ & $1(1.0)$ & $0(0.0)$ \\
\hline $\begin{array}{l}(\mathrm{m}) \text { I really disliked the prospect } \\
\text { of men and women together on a } \\
\text { small ward }\end{array}$ & 96 & $15(15.6)$ & $16(16.7)$ & $38(39.6)$ & $17(17.7)$ & $10(10.4)$ \\
\hline $\begin{array}{l}\text { (n) At no time did I feel that the } \\
\text { truth about my condition was } \\
\text { being hidden from me }\end{array}$ & 96 & $36(37.5)$ & $48(50.0)$ & $6(6.3)$ & $5(5.2)$ & $1(1.0)$ \\
\hline $\begin{array}{l}\text { (o) I had to ask for advice about } \\
\text { what I should and should not do } \\
\text { on discharge }\end{array}$ & 93 & $4(4.3)$ & $10(10.8)$ & $19(20.4)$ & $40(43.0)$ & $20(21.5)$ \\
\hline $\begin{array}{l}\text { (p) There was always a lovely } \\
\text { atmosphere on the unit }\end{array}$ & 97 & $44(45.4)$ & $45(46.4)$ & $6(6.2)$ & $2(2.1)$ & $0(0.0)$ \\
\hline $\begin{array}{l}\text { (q) From time to time the staff } \\
\text { gave me contradictory advice } \\
\text { about my condition }\end{array}$ & 97 & $0(0.0)$ & $9(9.3)$ & $10(10.3)$ & $42(43.3)$ & $36(37.1)$ \\
\hline
\end{tabular}




\begin{tabular}{|c|c|c|c|c|c|}
\hline Statement & $\begin{array}{c}\text { Total } \\
\text { responses }\end{array}$ & Total score & Mean score & $\begin{array}{l}\text { Standard } \\
\text { deviation }\end{array}$ & Rank \\
\hline $\begin{array}{l}\text { (I) I felt that I was being treated as an } \\
\text { individual by all members of staff }\end{array}$ & 98 & 433 & 4.42 & 0.67 & 1 \\
\hline $\begin{array}{l}\text { (k) The staff were always so helpful } \\
\text { and understanding over visiting times }\end{array}$ & 97 & 427 & 4.40 & 0.55 & 2 \\
\hline $\begin{array}{l}\text { (p) There was always a lovely } \\
\text { atmosphereon the unit }\end{array}$ & 97 & 422 & 4.35 & 0.69 & 3 \\
\hline $\begin{array}{l}\text { (j) The staff did everything possible to } \\
\text { help me with anxieties over my illness }\end{array}$ & 96 & 412 & 4.29 & 0.75 & 4 \\
\hline $\begin{array}{l}\text { (h) Overall, the staff could not have } \\
\text { been more friendly and approachable }\end{array}$ & 97 & 412 & 4.27 & 1.14 & 5 \\
\hline $\begin{array}{l}\text { (n) At no time did I feel that the truth } \\
\text { about my condition was being hidden } \\
\text { from me }\end{array}$ & 96 & 401 & 4.18 & 0.84 & 6 \\
\hline $\begin{array}{l}\text { (e) I never really knew what was } \\
\text { happening from } 1 \text { day to the next }\end{array}$ & 96 & 393 & 4.09 & 0.98 & 7 \\
\hline $\begin{array}{l}\text { (q) From time to time the staff gave me } \\
\text { contradictory advice about my } \\
\text { condition }\end{array}$ & 97 & 396 & 4.08 & 0.92 & 8 \\
\hline $\begin{array}{l}\text { (a) The staff gave me clear information } \\
\text { on how best to manage my illness }\end{array}$ & 96 & 390 & 4.06 & 0.75 & 9 \\
\hline $\begin{array}{l}\text { (b) Overall, I felt that I was talked at by } \\
\text { the staff rather than listened to }\end{array}$ & 96 & 386 & 4.02 & 0.91 & 10 \\
\hline $\begin{array}{l}\text { (g) I always felt that the purpose of my } \\
\text { prescribed medication was fully } \\
\text { explained }\end{array}$ & 96 & 378 & 3.94 & 0.91 & 11 \\
\hline $\begin{array}{l}\text { (f) I felt that I always gave my consent } \\
\text { before a clinical procedure was } \\
\text { carried out }\end{array}$ & 95 & 367 & 3.86 & 0.98 & 12 \\
\hline $\begin{array}{l}\text { (d) The subject of my treatment was } \\
\text { never properly discussed in any real } \\
\text { detail }\end{array}$ & 97 & 370 & 3.81 & 1.07 & 13 \\
\hline $\begin{array}{l}\text { (c) I wish I could have had more say in } \\
\text { my treatment and care }\end{array}$ & 94 & 354 & 3.77 & 0.88 & 14 \\
\hline $\begin{array}{l}\text { (o) I had to ask for advice about what I } \\
\text { should and should not do on } \\
\text { discharge }\end{array}$ & 93 & 341 & 3.67 & 1.06 & 15 \\
\hline $\begin{array}{l}\text { (i) Personally, I would have liked the } \\
\text { opportunity to read my medical notes }\end{array}$ & 97 & 295 & 3.04 & 1.06 & 16 \\
\hline $\begin{array}{l}\text { (m) I really disliked the prospect of } \\
\text { men and women together on a small } \\
\text { ward }\end{array}$ & 96 & 279 & 2.91 & 1.17 & 17 \\
\hline Total number of responses & 1634 & & - & - & \\
\hline Mean score per item & 379.8 & & - & - & \\
\hline Total possible score for matrix & 8170 & & - & - & \\
\hline Actual score for matrix & 6456 & & - & - & \\
\hline Satisfaction index $(6456 / 8170=79.0 \%)$ & & & - & - & \\
\hline
\end{tabular}


Table 6 Patients' responses to Likert-scale questions interpreted in terms of empowerment

\begin{tabular}{|c|c|c|c|c|c|}
\hline Category & $\begin{array}{l}\text { Number and }(\%) \text { of } \\
\text { patients completing } \\
\text { all } 17 \text { questions }\end{array}$ & Mean (S.D.) & $95 \% \mathrm{Cl}$ for mean & Maximum score & Minimum score \\
\hline $\begin{array}{l}\text { Very well-empowered } \\
\text { (mean score } 4.50 \text { or } \\
\text { over) }\end{array}$ & $14(15.7 \%)$ & $4.7(0.1)$ & $4.6-4.7$ & 4.8 & 4.5 \\
\hline $\begin{array}{l}\text { Well-empowered } \\
\text { (mean score } 4.00 \text { to } \\
4.49)\end{array}$ & 32 (35.9\%) & $4.2(0.1)$ & $4.1-4.2$ & 4.4 & 4.0 \\
\hline $\begin{array}{l}\text { Averagely empowered } \\
\text { (mean score } 3.50 \text { to } \\
3.99 \text { ) }\end{array}$ & $30(33.7 \%)$ & $3.7(0.1)$ & $3.6-3.7$ & 3.8 & 3.5 \\
\hline $\begin{array}{l}\text { Less than averagely } \\
\text { empowered (mean } \\
\text { score } 3.49 \text { or under) }\end{array}$ & $13(14.6 \%)$ & $3.2(0.1)$ & $3.1-3.2$ & 3.4 & 3.0 \\
\hline Overall & $89(99.9 \%)^{a}$ & $3.9(0.4)$ & $3.8-4.0$ & 4.8 & 3.0 \\
\hline
\end{tabular}


Patients were then asked some general questions about their stay in hospital. The question, in the form of a Likert-type patient satisfaction scale listed a total of 17 statements relating specifically to patient empowerment. Respondents were asked to tick the one box closest to their view and Table 4 presents results based on the numbers of patients who actually responded to each question.

It can be seen from statement (a) in Table 4 that a total of 96 patients completed this question of whom $25(26.0 \%)$ strongly agreed that the staff gave them clear information on how best to manage their illness and $57(59.4 \%)$ reportedly agreed with the statement. Thus, 82 of 96 patients $(85.4 \%)$ agreed overall while $5.2 \%$ disagreed. The largest numbers of positive responses were associated with items $(\mathrm{l}),(\mathrm{k}),(\mathrm{p}),(\mathrm{j}),(\mathrm{h})$ and $(\mathrm{n})$ and the largest numbers of negative responses with items $(\mathrm{m}),(\mathrm{i}),(\mathrm{o}),(\mathrm{c})(\mathrm{d})$ and $(\mathrm{f})$. These items are further discussed in Table 5.

From a total of 1634 responses, $1164(71 \%)$ were positive, $245(15 \%)$ were negative and 225 $(14 \%)$ were neither positive nor negative. Over a third of patients had no strong view about two issues-item $(\mathrm{m})$ men and women being nursed together on a small ward $(40 \%)$ and item (i) having the opportunity to read their medical notes.

In order to gain a better impression of how satisfied respondents were with aspects of patient empowerment and derive some form of perceived empowerment index, the 17 items were rescored on a five-point scale in such a way that the higher the score, the more satisfied the respondent. Positive statements were scored from $5=$ strongly agree to $1=$ strongly disagree, while negative statements were scored from $1=$ strongly agree to $5=$ strongly disagree.

A respondent, totally satisfied with all 17 elements of their stay in hospital, might generate a theoretical maximum score for the complete matrix of $17 \times 5=85$. Thus all 103 respondents, if they replied to each question, could in theory generate a maximum score of $17 \times 5 \times 103=$ 8755. From a total of 1634 responses, the maximum possible score for the matrix was calculated as $1634 \times 5=8170$.

Based on the five-point scoring system, it can be shown that the actual score for the matrix was 6456 . A score of $6456 / 8170$, expressed as a notional percentage of $79 \%$, would imply both an excellent measure of perceived patient satisfaction with respect to the coronary care unit arrangements.

Table 5, based on the scoring system outlined above, presents Likert-scale data scored and ranked according to mean scores. The mean score is 380 with 10 items falling above and 7 below it. Respondents ranked highest of all a shared view that they were treated as individuals by all members of staff. The second highest ranked item related to the staff's helpfulness and understanding over visiting times. Areas concerned with the warm, friendly, ward atmosphere, and reassuring, helpful, open and honest clinical staff all ranked highly.

Lowest ranked perceptions, about which there was concurrence, related to dislike of men and women being nursed together on a relatively small ward, enhanced opportunities to read medical notes and improved discharge advice.

An attempt was made to assess the internal consistency of the 17 item Likert-scale and the degree to which items comprising the scale all measured the same underlying attribute. Cronbach's alpha coefficient was 0.82. Although Nunnally (1978) recommends a minimum level of 0.7, Todd and Bradley (1994) have argued that alphas much in excess of 0.8 are usually indicative of redundancy within the scale, with alphas of less than 0.7 suggesting too diffuse a scale.

The Likert-scale data were further explored with respect to differences in perception between male and female and older and younger patients using the Chi-square test. There were no statistically significant differences with respect to gender or age groups on any of the 17 items. 
Table 6 presents results for the Likert-scale questions for the 89 patients who completed all the questions. A mean score over the 17 questions of 4.50 or higher is interpreted as very well empowered; a mean score from 4.00 to 4.49 interpreted as well empowered; a mean score between 3.50 and 3.49 as averagely empowered, and a mean score between 3.00 and 3.49 as less than averagely empowered. Overall, $14(16 \%)$ were very well-empowered, 32 (36\%) were well-empowered, $30(34 \%)$ were averagely empowered and $13(15 \%)$ were less than averagely empowered.

\section{Discussion}

The literature demonstrates that empowerment is neither a simple concept nor easily amenable to practice interventions by health care professionals. As a result, the research approach focused on identifying day-to-day benchmark indicators, consistent with empowerment as a technology (Tones, 2001).

In contrast to the accepted orthodoxy regarding patients' beliefs, willingness and ability to have power, influence and control, almost nine-tenths (87\%) of the study patients were content to entrust their care to the health professionals. This was based on their confidence in the clinical expertise, friendliness and approachability of the staff. There appeared to be no role conflict or demand for a re-shaping of the patient role. Equally there was no demand for a power sharing partnership or a relationship of equals, and patients seemed comfortable with the expertise gap, a 'high social distance' (Beattie, 1993, p. 185), and thus, in effect, the medical model and the sick role.

Our evidence suggests that high quality, skilled, professional care, prompt investigation and treatment and sensitive communication within a positive and comfortable environment were simply recognised by patients as facts of life in the coronary care unit. With regard to the commitment of health professionals to empower patients, our respondents report a very positive picture with a notional score of $79 \%$ overall on a patient empowerment index and only an estimated $15 \%$ reporting that they were less than averagely empowered overall. Regarding equality of opportunity and freedom from discrimination, the study demonstrated no differences in perception over empowerment issues with respect to gender or age. Perhaps most significantly, the coronary care patients in this study were only marginally interested in the patient empowerment agenda, which raises several questions about who is driving the empowerment debate, whose interests are being served and to what end. Nevertheless, when asked to reflect on a range of issues, patients were able easily to identify perceived shortfalls such as discharge advice, and options regarding their clinical notes and their nursing environment. This study showed that patients had a voice which was clearly heard by the health professionals caring for them. Perhaps, in the intensive and critical care situation, empowerment should best be seen as a process of enablement - not so much about retaining or relinquishing power - but rather about staff negotiating care by highlighting therapeutic options, facilitating patient defined outcomes and emphasising opportunities for patients to assume incremental responsibilities for their personal wellbeing.

\section{Limitations}

All the data collected retrospectively during periods of some emotional and physical trauma would have been subject to recall bias, and there must be a question about the robustness of patient recall about a month following discharge. It was assumed, however, that the unselected, consecutive sample would have the characteristics of a probability sample and that any unsystematic response errors would be self-compensating and cancel out over the whole sample. The relatively small sample size, located within only one NHS trust in England, permitted neither adequate consideration of the views of patients from ethnic minority backgrounds, nor the possibilities for multiple regression analysis in which patient empowerment could be explored in more depth with respect to key explanatory variables. Cronbach's alpha analysis indicated some item redundancy within the Likert-scale, possibly because some pairs of questions appeared to be opposites, e.g. (c) and (d) and (a) and (o), suggesting the need for refined instrumentation in future studies. Our findings relate to one specific, acute, critical care setting with life-threatening problems and we are not suggesting that they apply equally to other clinical milieus, although the extent to which patients wish to be expert patients clearly merits further research. 


\section{Conclusion}

The NHS plan (DoH, 2000) makes it clear that patient empowerment underpins the future development and delivery of health care. However, this study has suggested that empowerment issues involving the rights of patients to be primary decision makers, managers of their illnesses and ultimate arbiters of their treatment and care may, in some acute settings, be apparently alien to all but a few.

\section{References}

Beattie A. The changing boundaries of health. In: Beattie A, Gott M, Jones L, Sidell M, editors. Health and wellbeing. Milton Keynes: OU Press; 1993. p. 185.

Byrt R, Dooher J. Empowerment and participation: definitions, meanings and models. In: Dooher J, Byrt R, editors. Empowerment and participation: power, influence and control in contemporary health care, vol. 1. Quay Books, Trowbridge:Mark Allen; 2002.

Department of Health. Our healthier nation. London: The Stationery Office; 1998.

Department of Health. NHS plan: a plan for investment, a plan to reform. London: The Stationery Office; 2000.

Department of Health. The expert patient: a new approach to chronic disease management for the 21st century. London: Department of Health; 2001. Department of Health.

Patient advice and liaison service. London: Department of Health; 2002.

Department of Health. Choosing health: making healthy choices easier. London: Department of Health; 2004.

Gibson C. A concept analysis of empowerment. J Adv Nurs 1991;16:354-61.

Gibson C. The process of patient empowerment in mothers of chronically disabled children. $\mathrm{J}$ Adv Nurs 1995;21:1201-10.

Gilbert T. Nursing: empowerment and the problem of power. J Adv Nurs 1995;21:865-71.

Henwood F, Wyatt S, Hart A, Smith J. Ignorance is bliss sometimes: constraints on the emergence of the informed patient in the changing landscapes of health information. Sociol Health Illness 2003;25(6):589-607.

Hewitt-Taylor J. Challenging the balance of power on empowerment. Nurs Stand 2004;18(22):33-7.

Hogg C. Patients, power and politics. From patients to citizens. London: Sage Publications; 1999.

Hopkins A. Measures of the quality of life. London: Royal College of Physicians of London; 1992.

Humphries B. Preface. In: Humphries B, editor. Critical perspectives on empowerment. Birmingham: Venture Press; 1996.

Jacob F. Empowerment: a critique. Br J Commun Health Nurs 1996;1:449—553.

Kemshall H, Littlechild R. User involvement and participation in social care. Research informing practice. London: Jessica Kingsley; 2000.

Kendall S. Health and empowerment: research and practice. London: Arnold; 1998.

Kuokkanen L, Leino-Kilpi H. Power and empowerment in nursing: three theoretical approaches. J Adv Nurs 2000;31(1):235-41.

Laverack G,Wallerstein N. Measuring community empowerment: a fresh look at organisational domains. Health Promot Int 2001;16(2):179—85.

Malin N, Teasdale K. Caring versus empowerment: considerations for nursing practice. J Adv Nurs 1991;16(6):657-62.

McQueen D, White PD, Fuller R, Sharpe MC. Discomfort of patient power. Br Med J 2002;324(May):1214.

Moser C, Kalton G. Survey methods in social investigation. London: Heinemann Educational Books; 1977. p. 341-6, 416-27.

Munn P, Drever E. Using questionnaires in small-scale research: a teacher's guide. Edinburgh: The Scottish Council for Research in Education; 1995. p. 2.

NHSE. Health research: What's in it for consumers? First Report of the Standing Advisory Group on Consumer Involvement in the NHS Research and Development Programme. London: NHSE;1997.

Nunnally J. Psychometric theory. New York: Mcgraw-Hill; 1978. 
Nursing and Midwifery Council. Standards of proficiency for preregistration nursing education; 2004. www.nmc-uk.org [last accessed 19th October 2005].

Nursing and Midwifery Council. Consultation on a framework for the standard for postregistration nursing; 2005. www.nmcuk. org [last accessed 19th October 2005].

Oppenheim A. Questionnaire design, interviewing and attitude measurement. London: Pinter Publishers; 1992. p. 102.

Piper S, Brown P. The theory and practice of health education as applied to nursing: a bipolar approach. J Adv Nurs 1998;27:383-9.

Robson C. Real world research. Oxford: Blackwell; 1993.

Rodwell C. An analysis of the concept of empowerment. J Adv Nurs 1996;23:305-13.

Royal College of Nursing. Defining nursing. London: Royal College of Nursing; 2003.

Skelton R. Nursing and empowerment: concepts and strategies. J Adv Nurs 1994;19:415- 23.

Smith C. Validation of a patient satisfaction system in the United Kingdom. Qual Assurance Health Care 1992;4(3):171-7.

SPSS, SPSS Base 10.0 User's Guide. Chicago: SPSS; 1999.

Streiner D, Norman G. Health measurement scales: a practical guide to their development and use. Oxford: Oxford University Press; 1989.

Todd C, Bradley C. Evaluating the design and development of psychological scales. In: Bradley C, editor. Handbook of psychology and diabetes: a guide to psychological measurements in diabetes research and management. Chur, Switzerland: Harwood Academic Publishers; 1994.

Tones K. Health promotion and empowerment and the psychology of control. J Inst Health Educ 1991;29(1):17-26.

Tones K. Health education and the promotion of health: seeking wisely to empower. In: Kendall S, editor. Health and empowerment research and practice. London: Arnold; 1998.

Tones K. Health promotion: the empowerment imperative. In: Scriven A, Orme J, editors. Health promotion: professional perspectives. Basingstoke: Palgrave; 2001. p. 3-18.

Wilkinson G, Miers M. Power and nursing practice. Basingstoke: Macmillan; 1999.

Wikipedia. Flesch-Kincaid readability test; 2005. http://en.wikipedia.org/wiki/Flesch-Kincaid Readability Test. [last accessed 13th October 2005].

World Health Organisation. Declaration of Alma Ata; 1978.(www.who.int/hpr/archive/docs/almaata.html) last updated 1999, last accessed 12th December 2004. 